\title{
Effects of storage temperature on HMF and diastase activity of strained honeys*
}

\author{
Seda Dicle KORKMAZ ${ }^{1}$ Özlem KÜPLÜLÜ² \\ ${ }^{1}$ Giresun University, Espiye Vocational School, Food Processing Department, Giresun; ${ }^{2}$ Ankara University, Faculty of Veterinary \\ Medicine, Department of Food Hygiene and Technology, Ankara, Turkey.
}

\begin{abstract}
Summary: This research intends to reveal the effects of different storage temperatures on the HMF amounts and diastase activities of strained flower honey and honeydew honey samples produced by different companies in Turkey. In this context, the initial HMF values and diastase activities of the strained flower honey and honeydew honey samples belonging to five different companies, collected at the date of filling, were examined with defined quality criteria (moisture, sugar, $\mathrm{pH}$, acidity, electrical conductivity and ash). Samples were stored at certain temperatures $\left(10 \pm 2{ }^{\circ} \mathrm{C}, 22 \pm 2{ }^{\circ} \mathrm{C}, 35 \pm 2{ }^{\circ} \mathrm{C}\right)$, and were analyzed at the end of each of the threemonth periods (3rd, 6th, 9th and 12th months) regarding HMF and diastase activity. According to the results, average HMF values of the flower honey and honeydew honey samples stored at $10 \pm 2{ }^{\circ} \mathrm{C}$ and $22 \pm 2{ }^{\circ} \mathrm{C}$ for one year did not exceed $40 \mathrm{mg} / \mathrm{kg}$, which is given as the limit HMF value in the Turkish Food Codex (TFC) Directive on honey, while it rapidly increased in the samples stored at $35 \pm 2$ ${ }^{\circ} \mathrm{C}$, and was determined to be over $40 \mathrm{mg} / \mathrm{kg}$ as of 6 th month onwards. In addition, average diastase activities of the samples at $10 \pm 2$ ${ }^{\circ} \mathrm{C}$ and $22 \pm 2{ }^{\circ} \mathrm{C}$ did not drop below the limit value of 8 in TFC, though it was determined to be below 8 as of 6 th month onwards, for the flower honey stored at $35 \pm 2{ }^{\circ} \mathrm{C}$. To conclude, decrease in diastase activity shortens the shelf lives set by the firms. By providing proper production and storage conditions, all quality criteria should be ensured to remain consistent with the TFC Directive on honey.

Keywords: Diastase activity, HMF, honey, HPLC, storage temperature.
\end{abstract}

\section{Süzme ballarda muhafaza sıcaklığının HMF değeri ve diastaz aktivitesi üzerine etkisi}

Özet: Bu araştırmada Türkiye'de farklı firmalarca üretilen süzme çiçek ve salgı balı örneklerinin HMF miktarı ve diastaz aktivitesi üzerine farklı muhafaza sıcaklıklarının etkisinin ortaya konulması amaçlandı. Bu kapsamda fabrikalardan dolum tarihlerinde alınarak kalite kriterleri (nem, şeker, pH, asitlik, elektriksel iletkenlik, kül) belirlenen beş farklı firmaya ait süzme çiçek ve çam balı örneklerinin başlangıç HMF değeri ve diastaz aktiviteleri saptandı. Örnekler, belirli sıcaklıklarda $\left(10 \pm 2{ }^{\circ} \mathrm{C}, 22 \pm 2{ }^{\circ} \mathrm{C}, 35 \pm 2{ }^{\circ} \mathrm{C}\right)$ muhafaza edilerek üç aylık periyotlar (3, 6, 9 ve 12. ay) sonunda HMF ve diastaz aktivitesi yönünden analiz edildi. Elde edilen bulgulara göre, bir yıl boyunca $10 \pm 2{ }^{\circ} \mathrm{C}$ ve $22 \pm 2{ }^{\circ} \mathrm{C}$ 'de muhafaza edilen çiçek ve salgı balı örneklerinin ortalama HMF değerleri Türk Gıda Kodeksi (TGK) Bal Tebliği'nde sınır HMF değeri olarak belirtilen $40 \mathrm{mg} / \mathrm{kg}$ ' 1 aşmazken, $35 \pm 2{ }^{\circ} \mathrm{C}$ 'de muhafaza edilen örneklerde hızla artarak 6. aydan itibaren $40 \mathrm{mg} / \mathrm{kg}$ 'ın üzerinde saptand. Ayrıca örneklerin $10 \pm 2{ }^{\circ} \mathrm{C}$ ve $22 \pm 2{ }^{\circ} \mathrm{C}$ 'deki ortalama diastaz aktiviteleri TGK Bal Tebliği'nce belirtilen sınır değer olan 8 'in altına düşmezken $35 \pm 2{ }^{\circ} \mathrm{C}$ 'de muhafaza edilen çiçek balları için bu değer 6 . aydan itibaren 8'in altında saptand. Sonuç olarak tüketime sunulan süzme ballarda, gerek üretim sırasında uygulanan 1S1 işlemi, gerekse muhafaza sıcaklığına bağlı olarak artan HMF değeri ile azalan diastaz aktivitesi firmalarca belirlenen raf ömrünü kısaltmaktadır. Bala ait uygun üretim ve muhafaza koşulları sağlanarak, başta HMF ve diastaz olmak üzere tüm kalite kriterlerinin TGK Bal Tebliği'ne uygunluğu raf ömrünün sonuna kadar sağlanmalıdır.

Anahtar sözcükler: Bal, diastaz aktivitesi, HMF, HPLC, muhafaza sıcaklığı.

\section{Introduction}

Animal and/or vegetable-originated honey is known to be 'functional food', natural sweetener with high nutritional value, free from contaminants and safe for human consumption. As a good nutraceutical food, determination of honey and honey-based food quality is important for children, old people and patients.
Amount of hydroxy methyl furfural (HMF) and diastase activity are the two important parameters in the evaluation of honey freshness and quality $(1,4,5,11)$. Saliva of bee is the source of diastase (amylase) that is one of the most important enzymes making honey easily digestible. This enzyme degrades depending on the heat treatment and time applied to honey is a crucial indicator used in the determination of freshness of honey. However,

\footnotetext{
* This study was prepared from $\mathrm{PhD}$ thesis of first author and were presented as an oral presentation at the 6. Congress of the National Food Hygiene (7-11 Ekim 2015, Van)
} 
enzyme activity varies within considerably wide limits, even in fresh honeys $(2,8,13)$. According to Turkish Food Codex (TFC), Directive on honey (no:2012/58), diastase activity in flower honey and honeydew honey was determined to be at least 8 and 3, respectively. Diastase activity, so called diastase number, used for measuring enzyme is expressed as the amount of starch solution in $\mathrm{ml}$ of $1 \%$ that can be hydrolyzed by the enzyme in honey within one hour at $38-40{ }^{\circ} \mathrm{C}(16)$.

HMF is an important quality criterion formed as a result of dehydration of hexose in honey in an acidic environment and it varies depending on chemical characteristics of honey, like sugar, $\mathrm{pH}$, total acidity, honey processing, and storage temperature $(6,10,12,15)$. According to the above mentioned TFC on Turkish honey, HMF value is limited to be maximum $40 \mathrm{mg} / \mathrm{kg}$ in flower honey and honeydew honey products (16).

The aim of the research was to determine the HMF levels and diastase activities of flower honey and honeydew honey samples produced by different companies in Turkey, storaged at different temperatures.

\section{Materials and Methods}

Honey samples: For this study, a total of 30 honey samples in $850 \mathrm{~g}$ glass jars from 5 different honey producing companies (A, B, C, D, E), 3 flower honey and 3 honeydew honey samples from each, were obtained on the release date of the products.

$\mathrm{pH}$, moisture, ash, sugar, acidity, electrical conductivity and pollen analyses, HMF, and diastase activities were performed on the bottling day of the honey samples. The samples were kept at three different storage temperatures, $10 \pm 2{ }^{\circ} \mathrm{C}, 22 \pm 2{ }^{\circ} \mathrm{C}$ and $35 \pm 2{ }^{\circ} \mathrm{C}$, respectively; the analyses of $\mathrm{HMF}$ amounts and diastase activities were repeated at the end of each three-month period.

Sugar (fructose, glucose, sucrose) detection of the samples was determined by using HPLC - Refractive Index (RI) detector, in accordance with the method recommended by the International Honey Commission (IHC) (3). $\mathrm{pH}$ values of the samples were determined by using pH-meter (Hanna pH 211, Italy); and also their acidity was determined by the titrimetric methodology, in accordance with IHC. Electrical conductivity, moisture, and ash values were detected by using a conductivity meter (Meterlab-CDM230, Turkey), refractometer (Atago-Master M, Japan), and ash furnace (Protherm PFL/ 110, Turkey) respectively, by the method recommended by IHC (3). Additionally, pollens of flower honeys were counted under the light microscope (Olympus BH2, Japan) (7).

HMF analysis: HMF determination of the samples was performed by using HPLC-UV detector (Dionex, UltiMate 3000, Germany) according to an IHC method
(3). The instrument was calibrated with the standard of 99\% pure 5- hydroxymethyl- furan -2- carbaldehyde (HMF) (Merck CAS:820 678). The working standard solutions were prepared as $1,2,5$ and $10 \mathrm{mg} / \mathrm{L}$ for daily. The working standarts were transferred to $2 \mathrm{ml}$ vials and given to HPLC apparatus with UV detector capable of measuring at a wavelength of $285 \mathrm{~nm}$. Analyses were performed by using C18-reversed phase column (Hypersil ODS $5 \mu \mathrm{m}, 125 \times 4 \mathrm{~mm}$ ) under the isocratic mobile phase conditions including $90 \%$ distilled water-10\% methanol with a flow rate of $1.0 \mathrm{ml} / \mathrm{min}$ and injection amount was $10 \mu 1$.

Diastase analysis: Diastase number of honey samples were determined by using UV-Spectrophotometer (Rayleigh, VIS- 723G, England), according to the method recommended by IHC (3). Calibration of the starch solution to be used during the analysis was attained with an absorbency value of $600 \mathrm{~nm}$ in the UVSpectrophotometer; and the solution of sodium chloride $(\mathrm{NaCl})$ - acetate buffer required for analysis was prepared.

Honey solution was prepared by adding acetate buffer solution to $10 \mathrm{~g}$ of each sample. $10 \mathrm{ml}$ honey solution with $5 \mathrm{ml}$ starch solution in the test tubes were kept in distilled water for $15 \mathrm{~min}$ at $40{ }^{\circ} \mathrm{C}$. After that period, final solution was mixed again and transferred to the water bath. A $5 \mathrm{ml}$ diluted iodine solution was then added to each $0,5 \mathrm{ml}$ honey-starch solution with $11 \mathrm{ml}$ distilled water; this solution was mixed with 5-minute intervals; and the absorbance value was measured at the $5^{\text {th }}, 10^{\text {th }}, 15^{\text {th }}$ and $20^{\text {th }} \mathrm{min}$ at $600 \mathrm{~nm}$ range of $\mathrm{UV}$ Spectrophotometer for detection of the diastase activity.

\section{Results}

Sugar (fructose, glucose, sucrose, F/G, F+G), free acidity, $\mathrm{pH}$, moisture, electrical conductivity, pollen analyses, ash values, HMF and diastase activities of flower honey and honeydew honey samples obtained from factories of the companies A, B, C, D and E were analyzed for the initial $\left(0^{\text {th }}\right.$ day). The analyses results of the samples concerning the quality criteria were examined, and their suitability according to TFC Directive on honey was tested (Tables 1 and 2).

Honey samples collected from the factories were thoroughly analyzed with regards to all quality criteria and their adherence to the TFC honey notice was identified. The initial ( $0^{\text {th }}$ day) HMF values of the flower honey and honeydew honey samples were determined at the end of the 3-month periods after storage at selected temperatures $\left(10 \pm 2{ }^{\circ} \mathrm{C}, 22 \pm 2{ }^{\circ} \mathrm{C}\right.$ and $\left.35 \pm 2^{\circ} \mathrm{C}\right)$ are presented in Tables 3 and 4 below. The initial diastase activities and the diastase activities determined at the ends of the 3-month periods after storage at selected temperatures $\left(10 \pm 2{ }^{\circ} \mathrm{C}, 22 \pm 2{ }^{\circ} \mathrm{C}\right.$ and $35 \pm 2{ }^{\circ} \mathrm{C}$ ) are given in Tables 5 and 6 . 
Table 1 . The quality criteria for flower honey samples taken from factories.

Tablo 1. Fabrikalarından alınan çiçek ballarına ait kalite kriterleri.

\begin{tabular}{|c|c|c|c|c|c|c|c|c|}
\hline $\begin{array}{l}\text { Sample } \\
\text { name }\end{array}$ & $\begin{array}{l}\text { Sucrose } \\
\% \mathrm{~m} / \mathrm{m}\end{array}$ & $\begin{array}{l}\text { Fructose } \\
\% \mathrm{~m} / \mathrm{m}\end{array}$ & $\begin{array}{l}\text { Glucose } \\
\% \mathrm{~m} / \mathrm{m}\end{array}$ & $\begin{array}{c}\text { Moisture } \\
\%\end{array}$ & $\begin{array}{c}\text { Ash } \\
\%\end{array}$ & $\begin{array}{l}\text { Electrical Conductivity } \\
\mathrm{mS} / \mathrm{cm}\end{array}$ & $\mathrm{pH}$ & $\begin{array}{l}\text { Acidity } \\
\mathrm{meq} / \mathrm{kg}\end{array}$ \\
\hline A & 1.9 & 32.7 & 27.6 & 17.1 & 0.25 & 0.78 & 3.62 & 22.5 \\
\hline B & 2.9 & 33.6 & 28.5 & 18.3 & 0.21 & 0.65 & 3.52 & 24.6 \\
\hline $\mathrm{C}$ & 3.5 & 35.8 & 29.3 & 17.3 & 0.23 & 0.63 & 3.47 & 28.7 \\
\hline D & 3.1 & 36.2 & 31.4 & 16.8 & 0.19 & 0.45 & 3.45 & 29.3 \\
\hline $\mathrm{E}$ & 2.2 & 34.2 & 29.5 & 18.5 & 0.22 & 0.52 & 3.65 & 22.8 \\
\hline
\end{tabular}

Table 2. Quality criteria for the honeydew honey samples taken from factories.

Tablo 2. Fabrikalarından alınan çam ballarına ait kalite kriterleri.

\begin{tabular}{|c|c|c|c|c|c|c|c|c|}
\hline $\begin{array}{l}\text { Sample } \\
\text { name }\end{array}$ & $\begin{array}{l}\text { Sucrose } \\
\% \mathrm{~m} / \mathrm{m}\end{array}$ & $\begin{array}{l}\text { Fructose } \\
\% \mathrm{~m} / \mathrm{m}\end{array}$ & $\begin{array}{l}\text { Glucose } \\
\% \mathrm{~m} / \mathrm{m}\end{array}$ & $\begin{array}{c}\text { Moisture } \\
\%\end{array}$ & $\begin{array}{l}\text { Ash } \\
\%\end{array}$ & $\begin{array}{c}\text { Electrical Conductivity } \\
\mathrm{mS} / \mathrm{cm}\end{array}$ & $\mathrm{pH}$ & $\begin{array}{l}\text { Acidity } \\
\mathrm{meq} / \mathrm{kg}\end{array}$ \\
\hline A & 1.6 & 31.2 & 27.3 & 18.3 & 0.65 & 1.68 & 4.73 & 29.2 \\
\hline B & 2.5 & 30.4 & 25.7 & 17.5 & 0.58 & 1.61 & 4.54 & 28.3 \\
\hline $\mathrm{C}$ & 3.6 & 32.5 & 28.1 & 17.8 & 0.39 & 1.36 & 4.63 & 30.5 \\
\hline $\mathrm{D}$ & 3.0 & 33.1 & 28.8 & 16.9 & 0.26 & 1.15 & 4.27 & 32.1 \\
\hline $\mathrm{E}$ & 2.7 & 31.7 & 27.6 & 17.1 & 0.41 & 1.43 & 4.42 & 29.8 \\
\hline
\end{tabular}

Table 3. HMF values of the flower honey samples taken from factories, which varied at 3-month intervals at different storage temperatures ${ }^{\mathrm{a}}$.

Tablo 3. Fabrikalarından alınan çiçek balı örneklerinin farklı muhafaza sıcaklıklarında, 3 ay aralıklarla değişen HMF değerleria

\begin{tabular}{|c|c|c|c|c|c|c|}
\hline \multicolumn{2}{|c|}{ HMF value } & \multirow[t]{2}{*}{$0^{\text {th }}$ day } & \multirow{2}{*}{$\frac{3^{\text {rd }} \text { month }}{15.5 \pm 0.48}$} & \multirow{2}{*}{$\frac{6^{\text {th }} \text { month }}{17.9 \pm 0.64}$} & \multirow{2}{*}{$\frac{9^{\text {th }} \text { month }}{19.4 \pm 0.82}$} & \multirow{2}{*}{$\frac{12^{\text {th }} \text { month }}{21.8 \pm 0.74}$} \\
\hline & $10 \pm 2{ }^{\circ} \mathrm{C}$ & & & & & \\
\hline A & $22 \pm 2{ }^{\circ} \mathrm{C}$ & $14.2 \pm 0.65$ & $17.1 \pm 0.52$ & $20.9 \pm 0.68$ & $25.4 \pm 0.78$ & $29.1 \pm 0.83$ \\
\hline $\mathrm{n}=3$ & $35 \pm 2{ }^{\circ} \mathrm{C}$ & & $26.7 \pm 0.63$ & $60.2 \pm 0.76$ & $83.7 \pm 0.90$ & $132.8 \pm 0.96$ \\
\hline \multirow[b]{2}{*}{ B } & $10 \pm 2{ }^{\circ} \mathrm{C}$ & & $22.1 \pm 0.71$ & $23.3 \pm 0.73$ & $25.4 \pm 0.75$ & $27.7 \pm 0.88$ \\
\hline & $22 \pm 2{ }^{\circ} \mathrm{C}$ & $21.4 \pm 0.68$ & $25.0 \pm 0.55$ & $29.7 \pm 0.65$ & $35.3 \pm 0.84$ & $38.9 \pm 0.91$ \\
\hline $\mathrm{n}=3$ & $35 \pm 2{ }^{\circ} \mathrm{C}$ & & $37.9 \pm 0.64$ & $83.7 \pm 0.80$ & $115.0 \pm 0.92$ & $165.2 \pm 1.02$ \\
\hline \multirow[b]{2}{*}{$\mathrm{C}$} & $10 \pm 2{ }^{\circ} \mathrm{C}$ & & $10.5 \pm 0.42$ & $11.8 \pm 0.58$ & $12.9 \pm 0.63$ & $14.2 \pm 0.54$ \\
\hline & $22 \pm 2{ }^{\circ} \mathrm{C}$ & $9.7 \pm 0.53$ & $12.4 \pm 0.45$ & $15.8 \pm 0.64$ & $18.3 \pm 0.78$ & $22.1 \pm 0.82$ \\
\hline$n=3$ & $35 \pm 2{ }^{\circ} \mathrm{C}$ & & $24.7 \pm 0.60$ & $53.1 \pm 0.72$ & $121.2 \pm 0.87$ & $176.5 \pm 1.06$ \\
\hline \multirow[b]{2}{*}{$\mathrm{D}$} & $10 \pm 2{ }^{\circ} \mathrm{C}$ & & $16.8 \pm 0.42$ & $18.2 \pm 0.45$ & $18.9 \pm 0.94$ & $23.5 \pm 0.62$ \\
\hline & $22 \pm 2{ }^{\circ} \mathrm{C}$ & $15.7 \pm 0.60$ & $20.1 \pm 0.58$ & $24.9 \pm 0.77$ & $28.8 \pm 0.68$ & $35.6 \pm 0.77$ \\
\hline $\mathrm{n}=3$ & $35 \pm 2{ }^{\circ} \mathrm{C}$ & & $28.8 \pm 0.62$ & $71.4 \pm 0.69$ & $136.1 \pm 0.88$ & $198.5 \pm 1.20$ \\
\hline \multirow[b]{2}{*}{ E } & $10 \pm 2{ }^{\circ} \mathrm{C}$ & & $16.9 \pm 0.55$ & $17.8 \pm 0.52$ & $18.2 \pm 0.74$ & $20.1 \pm 0.87$ \\
\hline & $22 \pm 2{ }^{\circ} \mathrm{C}$ & $17.3 \pm 0.59$ & $20.5 \pm 0.62$ & $24.5 \pm 0.73$ & $29.1 \pm 0.85$ & $33.2 \pm 0.92$ \\
\hline $\mathrm{n}=3$ & $35 \pm 2{ }^{\circ} \mathrm{C}$ & & $29.8 \pm 0.45$ & $77.1 \pm 0.70$ & $110.7 \pm 0.94$ & $164.4 \pm 1.34$ \\
\hline
\end{tabular}

${ }^{\mathrm{a}}$ The analyses were performed in triplicate.

a Analizler üç kez tekrarlanmıştır. 
Table 4. HMF values of honeydew honey samples taken from factories, which varied at 3-month intervals at different storage temperatures ${ }^{\mathrm{a}}$.

Tablo 4. Fabrikalarından alınan çam balı örneklerinin farklı muhafaza sıcaklıklarında, 3 ay aralıklarla değişen HMF değerleria .

\begin{tabular}{|c|c|c|c|c|c|c|}
\hline \multicolumn{2}{|c|}{ HMF value } & \multirow[t]{2}{*}{$0^{\text {th }}$ day } & \multirow{2}{*}{$\frac{3^{\text {rd }} \text { month }}{11.1 \pm 0.53}$} & \multirow{2}{*}{$\frac{6^{\text {th }} \text { month }}{11.8 \pm 0.62}$} & \multirow{2}{*}{$\frac{9^{\text {th }} \text { month }}{11.8 \pm 0.75}$} & \multirow{2}{*}{$\frac{12^{\text {th }} \text { month }}{12.5 \pm 0.66}$} \\
\hline \multirow[b]{2}{*}{ A } & $10 \pm 2{ }^{\circ} \mathrm{C}$ & & & & & \\
\hline & $22 \pm 2{ }^{\circ} \mathrm{C}$ & \multirow[t]{2}{*}{$11.1 \pm 0.48$} & $13.2 \pm 0.46$ & $15.9 \pm 0.68$ & $19.3 \pm 0.72$ & $20.8 \pm 0.88$ \\
\hline \multirow[t]{2}{*}{$\mathrm{n}=3$} & $35 \pm 2{ }^{\circ} \mathrm{C}$ & & $19.0 \pm 0.52$ & $31.2 \pm 0.70$ & $51.4 \pm 0.88$ & $84.3 \pm 0.92$ \\
\hline & $10 \pm 2^{\circ} \mathrm{C}$ & \multirow{3}{*}{$13.9 \pm 0.56$} & $14.1 \pm 0.43$ & $14.6 \pm 0.63$ & $15.0 \pm 0.70$ & $15.8 \pm 0.59$ \\
\hline B & $22 \pm 2{ }^{\circ} \mathrm{C}$ & & $15.4 \pm 0.56$ & $17.1 \pm 0.67$ & $18.7 \pm 0.63$ & $21.8 \pm 0.84$ \\
\hline$n=3$ & $35 \pm 2{ }^{\circ} \mathrm{C}$ & & $22.7 \pm 0.50$ & $38.6 \pm 0.76$ & $52.9 \pm 0.82$ & $79.7 \pm 0.89$ \\
\hline \multirow[b]{2}{*}{$\mathrm{C}$} & $10 \pm 2{ }^{\circ} \mathrm{C}$ & \multirow{3}{*}{$12.4 \pm 0.52$} & $12.7 \pm 0.42$ & $12.6 \pm 0.48$ & $13.0 \pm 0.72$ & $13.4 \pm 0.62$ \\
\hline & $22 \pm 2{ }^{\circ} \mathrm{C}$ & & $14.4 \pm 0.48$ & $17.0 \pm 0.82$ & $19.8 \pm 0.57$ & $21.2 \pm 0.80$ \\
\hline$n=3$ & $35 \pm 2{ }^{\circ} \mathrm{C}$ & & $24.1 \pm 0.52$ & $41.0 \pm 0.78$ & $77.5 \pm 0.86$ & $115.8 \pm 0.97$ \\
\hline \multirow[b]{2}{*}{ D } & $10 \pm 2{ }^{\circ} \mathrm{C}$ & \multirow{3}{*}{$24.5 \pm 0.65$} & $25.6 \pm 0.56$ & $26.6 \pm 0.75$ & $26.8 \pm 0.78$ & $28.3 \pm 0.89$ \\
\hline & $22 \pm 2{ }^{\circ} \mathrm{C}$ & & $27.8 \pm 0.60$ & $30.8 \pm 0.82$ & $35.2 \pm 0.72$ & $41.4 \pm 0.92$ \\
\hline$n=3$ & $35 \pm 2{ }^{\circ} \mathrm{C}$ & & $39.6 \pm 0.63$ & $70.3 \pm 0.72$ & $102.2 \pm 0.95$ & $136.6 \pm 1.24$ \\
\hline \multirow[b]{2}{*}{$\mathrm{E}$} & $10 \pm 2^{\circ} \mathrm{C}$ & \multirow{3}{*}{$19.1 \pm 0.58$} & $20.1 \pm 0.47$ & $21.7 \pm 0.55$ & $21.5 \pm 0.75$ & $22.1 \pm 0.82$ \\
\hline & $22 \pm 2{ }^{\circ} \mathrm{C}$ & & $22.0 \pm 0.62$ & $23.8 \pm 0.52$ & $27.5 \pm 0.80$ & $32.2 \pm 0.89$ \\
\hline$n=3$ & $35 \pm 2{ }^{\circ} \mathrm{C}$ & & $27.8 \pm 0.62$ & $46.9 \pm 0.63$ & $63.1 \pm 0.93$ & $102.2 \pm 1.02$ \\
\hline
\end{tabular}

${ }^{a}$ The analyses were performed in triplicate.

a Analizler üç kez tekrarlanmıştır.

Table 5. Diastase activities of the flower honey samples taken from factories, which varied at 3-month intervals at different storage temperatures ${ }^{\mathrm{a}}$.

Tablo 5. Fabrikalarından alınan çiçek balı örneklerinin farklı muhafaza sıcaklıklarında, 3 ay aralıklarla değişen diastaz aktiviteleria

\begin{tabular}{|c|c|c|c|c|c|c|}
\hline \multicolumn{2}{|c|}{ Diastase activity } & \multirow[t]{2}{*}{$0^{\text {th }}$ day } & \multirow{2}{*}{$\frac{3^{\text {rd }} \text { month }}{13.0}$} & \multirow{2}{*}{$\frac{6^{\text {th }} \text { month }}{13.0}$} & \multirow{2}{*}{$\frac{9^{\text {th }} \text { month }}{12.7}$} & \multirow{2}{*}{$\frac{12^{\text {th }} \text { month }}{12.5}$} \\
\hline & $10 \pm 2^{\circ} \mathrm{C}$ & & & & & \\
\hline A & $22 \pm 2{ }^{\circ} \mathrm{C}$ & 13.2 & 12.8 & 12.0 & 11.5 & 10.9 \\
\hline $\mathrm{n}=3$ & $35 \pm 2{ }^{\circ} \mathrm{C}$ & & 10.9 & 8.7 & 8.0 & 6.9 \\
\hline \multirow[b]{2}{*}{ B } & $10 \pm 2{ }^{\circ} \mathrm{C}$ & & 10.8 & 10.6 & 10.5 & 10.1 \\
\hline & $22 \pm 2{ }^{\circ} \mathrm{C}$ & 10.8 & 10.4 & 9.7 & 9.3 & 8.7 \\
\hline $\mathrm{n}=3$ & $35 \pm 2{ }^{\circ} \mathrm{C}$ & & 9.3 & 7.8 & 7.1 & 6.2 \\
\hline \multirow[b]{2}{*}{$\mathrm{C}$} & $10 \pm 2^{\circ} \mathrm{C}$ & & 14.0 & 13.7 & 13.4 & 13.0 \\
\hline & $22 \pm 2{ }^{\circ} \mathrm{C}$ & 14.1 & 13.4 & 12.4 & 11.7 & 10.8 \\
\hline$n=3$ & $35 \pm 2{ }^{\circ} \mathrm{C}$ & & 12.1 & 9.8 & 8.6 & 6.3 \\
\hline \multirow[b]{2}{*}{$\mathrm{D}$} & $10 \pm 2{ }^{\circ} \mathrm{C}$ & & 12.4 & 12.2 & 11.7 & 11.0 \\
\hline & $22 \pm 2{ }^{\circ} \mathrm{C}$ & 12.7 & 12.0 & 11.2 & 10.4 & 9.1 \\
\hline$n=3$ & $35 \pm 2{ }^{\circ} \mathrm{C}$ & & 10.4 & 8.3 & 7.1 & 5.8 \\
\hline \multirow[b]{2}{*}{$\mathrm{E}$} & $10 \pm 2{ }^{\circ} \mathrm{C}$ & & 10.8 & 10.7 & 10.2 & 9.8 \\
\hline & $22 \pm 2{ }^{\circ} \mathrm{C}$ & 11.1 & 10.5 & 9.8 & 9.4 & 8.8 \\
\hline$n=3$ & $35 \pm 2{ }^{\circ} \mathrm{C}$ & & 9.5 & 7.6 & 6.8 & 6.0 \\
\hline
\end{tabular}

${ }^{\mathrm{a}}$ The analyses were performed in triplicate.

a Analizler üç kez tekrarlanmıştır. 
Table 6. Diastase activities of the honeydew honey samples obtained from factories presented at 3-month intervals at three different storage temperatures ${ }^{\mathrm{a}}$.

Tablo 6. Fabrikalarından alınan çam balı örneklerinin farklı muhafaza sıcaklıklarında, 3 ay aralıklarla değişen diastaz aktiviteleria

\begin{tabular}{|c|c|c|c|c|c|c|}
\hline \multicolumn{2}{|c|}{ Diastase activity } & \multirow[t]{2}{*}{$0^{\text {th }}$ day } & \multirow{2}{*}{$\frac{3^{\text {rd }} \text { month }}{14.2}$} & \multirow{2}{*}{$\frac{6^{\text {th }} \text { month }}{13.9}$} & \multirow{2}{*}{$\frac{9^{\text {th }} \text { month }}{13.9}$} & \multirow{2}{*}{$\frac{12^{\text {th }} \text { month }}{13.5}$} \\
\hline & $10 \pm 2^{\circ} \mathrm{C}$ & & & & & \\
\hline A & $22 \pm 2{ }^{\circ} \mathrm{C}$ & 14.3 & 13.9 & 13.2 & 12.8 & 12.2 \\
\hline$n=3$ & $35 \pm 2{ }^{\circ} \mathrm{C}$ & & 12.4 & 11.0 & 10.1 & 8.9 \\
\hline \multirow[b]{2}{*}{ B } & $10 \pm 2{ }^{\circ} \mathrm{C}$ & & 15.4 & 15.5 & 15.1 & 14.8 \\
\hline & $22 \pm 2{ }^{\circ} \mathrm{C}$ & 15.5 & 15.1 & 14.7 & 14.5 & 14.1 \\
\hline$n=3$ & $35 \pm 2{ }^{\circ} \mathrm{C}$ & & 13.5 & 12.7 & 12.0 & 11.0 \\
\hline \multirow[b]{2}{*}{$\mathrm{C}$} & $10 \pm 2{ }^{\circ} \mathrm{C}$ & & 16.5 & 16.2 & 16.0 & 15.6 \\
\hline & $22 \pm 2{ }^{\circ} \mathrm{C}$ & 16.7 & 16.0 & 15.2 & 14.6 & 13.7 \\
\hline$n=3$ & $35 \pm 2{ }^{\circ} \mathrm{C}$ & & 13.6 & 12.3 & 11.1 & 9.2 \\
\hline \multirow[b]{2}{*}{$\mathrm{D}$} & $10 \pm 2^{\circ} \mathrm{C}$ & & 12.9 & 12.4 & 11.9 & 11.2 \\
\hline & $22 \pm 2{ }^{\circ} \mathrm{C}$ & 12.9 & 12.4 & 11.8 & 11.4 & 10.8 \\
\hline$n=3$ & $35 \pm 2{ }^{\circ} \mathrm{C}$ & & 10.9 & 9.5 & 8.8 & 7.9 \\
\hline \multirow[b]{2}{*}{ E } & $10 \pm 2{ }^{\circ} \mathrm{C}$ & & 14.9 & 14.6 & 13.9 & 13.3 \\
\hline & $22 \pm 2{ }^{\circ} \mathrm{C}$ & 14.9 & 14.0 & 13.2 & 12.3 & 11.1 \\
\hline$n=3$ & $35 \pm 2{ }^{\circ} \mathrm{C}$ & & 12.2 & 10.7 & 9.2 & 8.9 \\
\hline
\end{tabular}

${ }^{\mathrm{a}}$ The analyses were performed in triplicate.

${ }^{a}$ Analizler üç kez tekrarlanmıştır.

\section{Discussion and Conclusion}

According to the results of the analyses of all the samples obtained from the factories at the date of their bottling (fructose, glucose, sucrose, F/G, F+G), free acidity, $\mathrm{pH}$, moisture, electrical conductivity, ash, HMF and diastase values), all of the honey samples have been determined to be compatible with the TFC Directive on honey (Tables 1 and 2).

As shown in above mentioned Table 3, initial HMF values of the flower honey samples obtained from the brands A, B, C, D, E varied between 9.7-21.4 mg/kg; while the HMF values of the samples stored at $10 \pm 2,22 \pm 2$ and $35 \pm 2{ }^{\circ} \mathrm{C}$ varied between 14.2-27.7, 22.1-38.9 and $132.8-198.5 \mathrm{mg} / \mathrm{kg}$, respectively in the analyses performed at the end of the $12^{\text {th }}$ month period. From the view of the point, $\mathrm{HMF}$ values of the samples at $10 \pm 2$ and $22 \pm 2{ }^{\circ} \mathrm{C}$ are not more than $40 \mathrm{mg} / \mathrm{kg}$ based on the limit value in the TFC Directive on Honey; whilst all the samples stored at $35 \pm 2{ }^{\circ} \mathrm{C}$ have values exceeding the limit value from the $6^{\text {th }}$ month and on. In Table 4 , the initial HMF values of the honeydew honey samples varied between 11.1- $24.5 \mathrm{mg} / \mathrm{kg}$; whereas the HMF values of the samples stored at $10 \pm 2,22 \pm 2$ and $35 \pm 2{ }^{\circ} \mathrm{C}$ varied to be between 12.5-28.3, 20.8-41.4 and 79.7-136.6 mg/kg, respectively, in the analyses performed at the end of the $12^{\text {th }}$ month.

Accordingly, except for the honeydew honey of the brand $\mathrm{D}$ at $22 \pm 2{ }^{\circ} \mathrm{C}$, the HMF values of all the samples stored at $10 \pm 2$ ve $22 \pm 2{ }^{\circ} \mathrm{C}$ were observed not to exceed 40 $\mathrm{mg} / \mathrm{kg}$; while it was ascertained that the honeys of the brands $\mathrm{C}, \mathrm{D}$ and $\mathrm{E}$ stored at $35 \pm 2{ }^{\circ} \mathrm{C}$ exceeded the limit value at the $6^{\text {th }}$ month, and the honeys of the brands $\mathrm{A}$ and B exceeded the limit value after the 9 months.

It can be seen that the initial ( $0^{\text {th }}$ day $)$ diastase activities of the flower honey samples varied between $10.8-14.1 \mathrm{mg} / \mathrm{kg}$ whereas that of the samples stored at $10 \pm 2,22 \pm 2$ and $35 \pm 2{ }^{\circ} \mathrm{C}$ were found between 9.8-13.0, 8.7-10.9 and 5.8-6.9 mg/kg, respectively, in the analyses performed at the end of the $12^{\text {th }}$ month (Table 5). According to these findings, diastase activities of the studied samples at $10 \pm 2$ and $22 \pm 2{ }^{\circ} \mathrm{C}$ did not decrease below the 8 score that is the limit value for Turkish Food Codex. Directive rules on honey and honey-based products; diastase activities of all samples stored at $35 \pm 2$ ${ }^{\circ} \mathrm{C}$ were found below the limit value. Table 6 shows that the initial ( $0^{\text {th }}$ day) diastase activities of honeydew honey samples varied between $12.9-16.7 \mathrm{mg} / \mathrm{kg}$. Diastase activities of the samples stored at $10 \pm 2,22 \pm 2$ and $35 \pm 2{ }^{\circ} \mathrm{C}$ were determined between 11.2-15.6, 10.8-14.1 and 7.9$11.0 \mathrm{mg} / \mathrm{kg}$, respectively at the end of the $12^{\text {th }}$ month (Table 6). According to, the diastase activities of all the honeydew honey samples stored at $10 \pm 2,22 \pm 2$ and $35 \pm 2$ ${ }^{\circ} \mathrm{C}$ except for the brand $\mathrm{D}$ at $35 \pm 2{ }^{\circ} \mathrm{C}$ were found in accordance with the TFC. The diastase activity of the honeydew honey brand D was determined as 7.9 and was found below the limit value. 
The average $\mathrm{HMF}$ values of the flower honey and honeydew honey samples stored at $10 \pm 2{ }^{\circ} \mathrm{C}$ and $22 \pm 2{ }^{\circ} \mathrm{C}$, measured at the end of the $12^{\text {th }}$ month, were found to be in accordance with the Turkish Food Codex. Based on the Directive on honey (16); HMF data of honey samples at $35 \pm 2{ }^{\circ} \mathrm{C}$ should not be exceeded the limit value $(40 \mathrm{mg} / \mathrm{kg})$ at the $6^{\text {th }}$ month.

Effects of the storage temperatures on diastase activities were examined and found that flower honey samples at $35 \pm 2{ }^{\circ} \mathrm{C}$ approached the limit value of 8 from the $6^{\text {th }}$ month $(8.44 \pm 0.39)$ in the TFC. Diastase activity values were observed to be under the limit value from the $9^{\text {th }}$ month. Moreover, diastase values all the samples at 10 $\pm 2{ }^{\circ} \mathrm{C}$ and $22 \pm 2{ }^{\circ} \mathrm{C}$ were found in accordance with the relevant directive at the end of the $12^{\text {th }}$ month. Average diastase activity of the honeydew honeys stored at $35 \pm 2$ ${ }^{\circ} \mathrm{C}$ was determined as $14.86 \pm 0.63$ on the bottling day $\left(0^{\text {th }}\right.$ day) and dropped down to $9.18 \pm 0.50$ at the end of the $12^{\text {th }}$ month. It seems that owing to the effect of the temperature, honeydew honeys contain high level of diastase enzyme, the obtained results caused higher values than the limit values. This situation reveals that initial values of honeys depend on the storage temperature and time.

After the storage of flower honey and honeydew honey samples during one year, the alterations of the individual HMF values and diastase activities were achieved for three different temperatures. It is seen that the exposition during the storage time is crucial for the honey quality control, and its quality marker as HMF values and diastase activities. In the study, brand B flower honey had the highest initial HMF value and lowest initial diastase activity while the brand $\mathrm{D}$ honeydew honey had HMF values the closest to the limit value at $35 \pm 2{ }^{\circ} \mathrm{C}$ at the end of the $3^{\text {rd }}$ month. The diastase activity of brand $\mathrm{B}$ was measured and was found below the limit level at the end of the $6^{\text {th }}$ month.

It is known that HMF level is usually low during harvest season, this level rises as uncontrolled manner because of the long-term thermal processes in processing conditions. It is known that thermal processing have been applied for prevention of fermentation and for suitability of storing during long time without crystallization. From the view point of the marketing quality of honeys, the quality depends on the HMF values; if HMF increases, diastase enzymes decrease and consequently cause the quality loss of the samples; that is leading their nutritional values to diminish due to improper storage conditions.

Yilmaz \& Küfrevioğlu (2001) determined the HMF values and diastase activities of 45 honey samples by spectrophotometrical methods, and stored them for a year at $20 \pm 5{ }^{\circ} \mathrm{C}$. With the analysis at the end of the year, the average HMF value initially determined to be $3.3 \mathrm{mg} / \mathrm{kg}$ increased up to $19.1 \mathrm{mg} / \mathrm{kg}$, while the average diastase activity dropped down from 14.6 to 10.7 . In their study, increase $(16.12 \mathrm{mg} / \mathrm{kg})$ in the average HMF value and decrease in diastase activities (2.72) of flower honey samples stored at $22 \pm 2{ }^{\circ} \mathrm{C}$ are similar to the abovementioned results (17). In current study, we found suitable quantitative levels for the HMF levels for all the samples stored at room temperature $\left(24 \pm 1{ }^{\circ} \mathrm{C}\right)$ not exceed the limit values acceptable by the TFC. This situation showed that utilized honeys had stored at appropriate conditions and proper for the Directive on honey, in terms of HMF value.

Sahinler (9) examined the HMF values and diastase activities that changed in honey samples stored at room temperature for a year after keeping the samples at 55, 65 and $75^{\circ} \mathrm{C}$ for $15,30,45$ and 60 minutes, respectively. At the room temperature, HMF values and diastase activities of honey samples were determined as $17.6 \mathrm{mg} / \mathrm{kg}$ and 13.6, respectively, at the end of the $9^{\text {th }}$ month. In this study, on the other hand, the increase in HMF value was found to be higher, whil diastase activity was found to be lower. This is thought to be caused by the initial values depending on long-term storage at improper storage conditions (high storage temperature) after harvest as a consequence of high temperatures that honeys are exposed to during their processing stage at processing stage in the factories.

Initial HMF values of the honey samples that Sancho et al. (11) stored at room temperature for a year are in agreement with that of the honeys kept waiting at $22 \pm 2{ }^{\circ} \mathrm{C}$ in this study, in terms of the the increase in the HMF values of the samples.

The HMF and diastase values of 40 honey samples obtained after harvesting by Turhan (14) the average values were determined to be $4.5 \mathrm{mg} / \mathrm{kg}$ and 16.3 , respectively, by means of spectrophotometric methods. Average HMF values and diastase activities of the samples stored at $25{ }^{\circ} \mathrm{C}$ for a year were determined to be 25.6 $\mathrm{mg} / \mathrm{kg}$ and 11.4 respectively, at the end of the storage period. The increase in HMF values of the honeys stored at room temperature in that study was found to be compatible with the above values (14). On the other hand, the slower decrease in diastase activities suggests that the enzyme degrades rapidly at the beginning owing to thermal processing of the samples, and then the decrease of the degradation.

Temperature and time-dependent alterations of the values of the honey sample stored at 10,20 and $40{ }^{\circ} \mathrm{C}$ for 12 months were measured in a study carried out by Castro - Vàzquez et al. (4). The findings are similar to the results of the samples stored at $10 \pm 2$ and $22 \pm 2{ }^{\circ} \mathrm{C}$ in our study while the ones kept waiting at $35 \pm 2{ }^{\circ} \mathrm{C}$ had lower HMF values and higher diastase activities in comparison with that of the ones kept at $40{ }^{\circ} \mathrm{C}$.

In this study, the effect of different storage temperatures on HMF values and diastase activities of strained honeys produced by different companies in Turkey were investigated. It is found that the average 
HMF values of all the samples stored at $35 \pm 2{ }^{\circ} \mathrm{C}$ for one year were considerably higher and their diastase activities were highly lower than that of the stored at $10 \pm 2{ }^{\circ} \mathrm{C}$ and $22 \pm 2{ }^{\circ} \mathrm{C}$. This data emphasized that the storage temperature is important as the quality indicator for honeys. Diastase activity decreased due to both heat treatment applied during production and HMF value increased owing to storage temperature; so these situations resulted in quality loss in strained honey and decreased the shelf life of commercial products. HMF that forms in honey standing an important place in healthy nutrition is known to be a potential risk in terms of food safety and public health. Suitability of the all the quality criteria, HMF and diastase criteria in particular, must therefore be ensured to be within the values in the TFC Directive on honey throughout the shelf life, by providing production and storage conditions suitable for honey.

Following the completion of this study, alterations have been made to transportation and storage sections of TFC Directive on honey. According to the updated codex, article 14 now dictates that honey be stored at no more than $25^{\circ} \mathrm{C}$.

\section{Acknowledgement}

This study was supported by Ankara University Research Fund (Project No: 10B3338011). The authors would like to thank Ankara University for their support.

\section{References}

1. Ajlouni S, Sujirapinyokul P (2009): Hydroxymethylfurfuraldehyde and amylase contents in Australian honey. Food Chem, 119, 1000-1005.

2. Belitz HD, Grosch W (1999): Food chemistry (2nd ed.). Berlin: Springer-Verlag, pp. 821-828.

3. Bogdanov S (2009): Harmonised methods of the international honey commission. IHC responsible for the methods; Bee Product Science, 9-54.

4. Castro Vàzquez L, Díaz Maroto MC, Gonzàlez Vinas MA, et al. (2008): Influence of storage conditions on chemical composition and sensory properties of citrus honey. J Agric Food Chem, 56, 1999-2006.

5. Fallico B, Zappalà M, Arena E, et al. (2004): Effects of conditioning on HMF content in unifloral honeys. Food Chem, 85, 305-313.
6. Fallico B, Arena E, Zappalà M (2009): Prediction of honey shelf life. J Food Quality, 32, 352-368.

7. Moar NT (1985): Pollen analysis of New Zealland honey. J Agr Res, 28, 38-70.

8. Morales V, Sanz ML, Martin-Alvarez PJ, et al. (2000): Combined use of HMF and furosine to assess fresh honey quality. J Sci Food Agric, 89, 1332-1338.

9. Sahinler N (2007): Effects of heating and storage on hydroxymethylfurfural and diastase activity of different Turkish honeys. J Apicult Res, 46, 34-39.

10. Sahinler N, Sahinler S, Gül A (2001): Hatay yöresi ballarının bileşimi ve biyokimyasal analizi. MKÜ Ziraat Fak Derg, 6, 93-108.

11. Sancho TM, Muniata S, Huidobro FJ, et al. (1992): Aging of honey. J Agr Food Chem, 40, 134-138.

12. Teixido E, Santos FJ, Puignou L, et al. (2006): Analysis of 5-hydroxymethyfurfural in foods by gas chromatographymass spectrometry. J Chromatogr A, 1135, 85-90.

13. Tosi E, Ciappini M, Lucero H (2002): Honey thermal treatment effects on hydroxymethyfurfural content. Food Chem, 77, 71-74.

14. Turhan K (2008): Effect of thermal treatment and storage on HMF content and diastase activity of honeys collected from Middle Anatolia in Turkey. 233-239 In: B Sener (Ed.), Innovations in Chemical Biology, Springer, Berlin.

15. Turgay Ö (2009): Characteristic properties of Kahramanmaraş honey samples. KSU Doğa Bilimleri Dergisi, 12, 21-24.

16. Türk Gıda Kodeksi Bal Tebliği (2012): No: 2012/58, 27/07/2012, Türkiye. http://www.resmigazete.gov.tr/eskiler/2012/07/2012072712.htm

17. Yılmaz H, Küfrevioğlu İ (2001): Doğu ve Güneydoğu Anadolu bölgelerinden toplanan ballarin bilesimi ve depolamanin HMF miktarl ve diastaz aktivitesine etkisi. Turk J Agric For, 25, 347-349.

Geliş tarihi:13.07.2016 / Kabul tarihi: 07.02.2017
Address for correspondence:
Yrd. Doç. Dr. Seda Dicle KORKMAZ
Giresun Üniversitesi, Espiye Meslek Yüksekokulu,
Gida İşleme Bölümü,
Gıda Kalite Kontrolü ve Analizi Programı,
Espiye, Giresun, Türkiye.
e-mail:diclekahraman@giresun.edu.tr 